\title{
Relationship Between Personality Traits and Attitude Toward Inclusive Education in Indonesian Preschool Teachers
}

\section{Chairunnisa Rizkiah ${ }^{\mathrm{a}}$ and Farida Kurniawati ${ }^{\mathrm{b}}$}

${ }^{a}$ Faculty of Psychology, University of Indonesia, Depok, Indonesia; ${ }^{b}$ Department of Educational Psychology, Faculty of Psychology, University of Indonesia. Depok, Indonesia

*Corresponding author:

Farida Kurniawati

Department of Educational Psychology

Faculty of Psychology, Universitas Indonesia

Jl. Lkr. Kampus Raya, Depok, Jawa Barat

Indonesia, 16424

Tel.: +62 217270004

Email address: farida1@ui.ac.id / fafadana@gmail.com 


\title{
Relationship Between Personality Traits and Attitude Toward Inclusive Education in Indonesian Preschool Teachers
}

\begin{abstract}
This study investigated the relationship between the preschool teacher personality traits determined using Costa-McCrae's Five Factor Model of Personality and the individual attitude toward inclusive education, and also examined whether this attitude was affected by teaching experience and professional development. The NeuroticismExtraversion-Openness Personality Inventory (NEO-PI) and the Indonesian Version of the Multidimensional Attitudes Toward Inclusive Education Scale (MATIES VI) were administered to 90 Indonesian preschool teachers. It was found that the Openness to Experience trait correlated significantly with the cognitive domain of the teacher attitudes, with all five traits significantly correlating with the affective attitude domain, and all traits except Neuroticism correlating significantly with the behavioral attitude domain. Teaching experience, however, was not found to have any significant effect on teacher attitude, and the participants' affective domain scores differed depending on whether or not they had had inclusive education professional development. The implications of these findings are discussed in relation to international studies and suggestions given for effective inclusive education interventions for Indonesian preschool teachers.
\end{abstract}

Keywords: attitude, inclusive education, personality trait, preschool, teacher

\section{Introduction}

Inclusion, which is when children with special needs are educated together with non-special needs children, requires social connectedness, participation, exchange and shared responsibility (Ferguson et al., 1992, as cited in Pallas, 2001). Therefore, to ensure that such inclusion is effective, teachers need to ensure that special needs students are fully included in the class. Darling-Hammond (2006) claimed that effective inclusive education models require a collaboration between inclusive education experts and classroom teachers because the teachers need to be able to apply a range of diverse teaching strategies depending on the various special needs conditions, which is a major challenge as it requires the teachers to be continually learning. Malouf and Schiller (1995) (as cited in Pallas, 2001) also claimed that a teacher's learning process was a combination of new and pre-existing knowledge, and argued that personal experiences that give rise to new beliefs or perceptions can change a teacher's belief systems and consequently their attitudes toward certain issues such as the placement of special educational needs (SEN) students in regular schools.

Kurniawati, Minnaert, Mangunsong, and Ahmed (2012) found in a study on Indonesian primary school teachers that in general, teachers had a positive attitude toward inclusive education; that is, although the cognitive and affective attitude dimension results appeared to disagree with placing SEN students in regular classroom, the behavioral dimensional results indicated a willingness to assist the SEN students. Bendová, Čecháčková, and Šádková (2014) examined preschool teachers in the Czech Republic and found that the teachers had a neutral attitude toward SEN education. However, in a study on Egyptian preschool and elementary teachers, Emam and Mohamed (2011) found that the longer the teaching experience, the more negative 
the attitudes toward inclusive education; that is, teachers who had less than 5 years teaching experience had more positive attitudes than teachers with 5-10 years teaching experience, and teachers with more than 10 years teaching experience had the most negative attitudes.

Therefore, not all teachers have a positive attitude toward inclusive education; even though in the behavioral dimension they are willing to assist SEN students, cognitively and affectively they may not have a positive attitude. These findings contradicted Sapon-Shevin (in the Directorate of Special Education and Special Services in Primary Education of Indonesia, 2012), who claimed that one of the five learning profiles in inclusive schools was to create and maintain a warm class community, accept diversity, and appreciate differences. However, to implement these characteristics requires a positive teacher attitude toward SEN inclusion so as to be a role model for the other students. Minke et al. (1996) (as cited in Pallas, 2001) and Zigmond and Baker (1996) (as cited in Pallas, 2001) also stated that inclusion could only be successful if staff had a positive attitude toward the concept.

Attitudes can be influenced by various factors such as personality traits, which are the individual characteristics that influence a broad range of trait-relevant responses (Ajzen, 2005). Several studies found that teacher attitudes toward inclusive education were closely connected to their personalities. For example, Todorovic, Stojiljkovic, Ristanic, and Djigic (2011) found that a positive attitude toward inclusive education correlated with the Openness to Experience trait in the Costa-McCrae's Five Factor Model of Personality (FFM), and Prather-Jones (2011) found that teacher attitudes toward students with special emotional and behavioral problems (EBD) were also related to personality characteristics such as intrinsic motivation, flexibility, enjoyment of variety, and a genuine interest in EBD children. Teacher attitudes toward inclusive education have also been found to be influenced by experience and professional development. Bentea (2015) found that teachers who had a positive attitude toward their profession tended to have certain dispositions: "generosity", which includes a willingness to be involved and act on behalf of others and to solve common problems; "claim" which involves having good analytics and observation skills to be able to perceive any dysfunctions in the social system to which they belong (organization, group, family) or any violation of their rights, be able to react immediately, and have the courage to express their position in front of colleagues or principals; "involved", which means to be involved in causes that are not own so as to resolve common problems and to help others without waiting for anything in return and without feeling a special effort or sacrifice; and "altruistic-selfishness", which involves offering to help, being willing to intervene to resolve common problems; and having an internal locus of control.

The National Council for the Accreditation of Teacher Education (NCATE; 2001, as cited in Damon, 2007) claimed that the factors most required when selecting teachers were knowledge, skills, and disposition, with knowledge and skills being the learning outcomes from the educational process and experience, and disposition being the teacher's personal characteristics. NCATE defined disposition as the "value, commitment, and professional ethics that influence behavior toward students, family, colleagues and community and influence student learning, motivation, and development, as well as the professional growth of the educators themselves." 
The demographic factors that have been found to be related to teacher attitudes toward inclusive education were experience and professional development. Robinson (2017) claimed that the lack of understanding about and lack of training in inclusive education could affect the attitudes of pre-service and in-service teachers toward inclusive education policies, and Jordan, Schwartz, and McGhie-Richmond (2009) found that education practitioners were confused about inclusion, inclusive practices, and identifying special needs/NES students because of the lack of professional development for teachers in inclusive schools. Darling-Hammond (2006) argued that as the world student population was changing rapidly, strategies that had proven effective in the past may not necessarily be suitable today, and therefore teachers needed to receive specific professional development for inclusive classes.

\section{Personality Traits}

Costa and McCrae ( 2003) claimed that traits are "endogenous basic tendencies that give rise to consistent patterns of thoughts, feelings, and actions". Feist and Feist (2006) then proved that Costa and McCrae's method for assessing personality traits was empirical, replicable, had parsimony principles and high internal consistency. Costa and McCrae's "Five Factor Theory of Personality" (FFT), which was based on the Five Factor Model (FFM) (1990) (as cited in McCrae and Costa, 2003), recognizes the five basic human traits; neuroticism, extraversion, openness to experience, agreeableness, and conscientiousness.

Trait Neuroticism is associated with negative affect such as anxiety, fear, anger, irritability, feelings of despair, and feelings of guilt and shame and has six main facets: anxiety, angry hostility, depressiveness, self-consciousness, impulsiveness, and vulnerability. Trait Extraversion is related to interpersonal interactions and level of activity and has the following six main facets: warmth, gregariousness, assertiveness, activity, excitement seeking, and positive emotions. Trait Openness to Experience is related to the active seeking of information; it has six main facets: fantasy, aesthetics, feelings, actions, ideas, and values. Trait Agreeableness is related to a sense of trust and a willingness to help others and has six main facets: trust, straightforwardness, altruism, compliance, modesty, and tender-mindedness. Trait Conscientiousness is related to responsibility, perseverance, and setting goals; it has the following six main facets; competence, order, dutifulness, achievements from striving, selfdiscipline, and deliberation (Widiger, Costa, \& McCrae in Costa \& Widiger, 2002).

\section{Teacher's attitudes toward inclusive education}

Attitude is the disposition to respond un/favorably to an object, person, institution, or event (Ajzen \& Fishbein, 2000, as cited in Azjen, 2005). The Theory of Planned Behavior (Azjen, 2005) sees attitude as a key component of behavioral intentions. Therefore, an attitude toward inclusive education is a teacher's positive/negative attitude toward educating all children (including SEN) in public schools and the degree to which they accept these responsibilities as part of their professional duties (Symeonidou \& Phtiaka, 2009). Ajzen (2005) claimed that there were three attitude dimensions; cognitive, affective, and behavioral. Mahat (2008) believed that the cognitive dimension was related to a teacher's belief about inclusive education, SEN, and the presence of SEN children in inclusive schools, the affective dimension was related to the teacher's feelings toward inclusive education and SEN, and the behavioral 
dimension was related to behavioral intentions, tendencies to act, and actions toward the objects of the attitudes. Personal experience has also been identified as a factor that could influence the strength of attitude, with attitudes derived from direct experience being more likely to be stronger and more likely to arise when there are objects that are subject to the attitude (Tormala, Petty, \& Brinol, 2002, as cited in Baron, Branscombe, \& Byrne, 2008).

\section{The Current Study}

The current study was a preliminary study for an intervention program for preschool teachers in inclusive Indonesian preschools to determine whether there was a significant relationship between teacher attitudes toward inclusive education and teacher personality traits based on Costa-McCrae's FFM, from which it was expected to determine the strength of the relationship between the preschool teachers' attitudes and their personalities, thus allowing for the development of appropriate interventions to ensure effective inclusive education in Indonesia.

Teaching requires practitioners to have care, sensitivity, dedication and competence. As found in previous studies, the relationships between trait openness and attitude toward inclusive education are related to those aspects of a teacher's personality related to a willingness to learn and accept new things. Preschool teachers were the target population for this study because preschool (3-6 years) is the child development period in which children start to explore different settings outside their homes. Therefore, as early intervention for SEN children can benefit their development, the preschool teacher is vital to ensuring successful development.

Therefore, the research questions are as follows:

RQ1. Is there a significant relationship between each of the FFM personality traits and teacher attitudes toward inclusive education in the cognitive, affective, and behavioral dimensions?

RQ2. Is there a significant relationship between teaching experience and teacher attitudes toward inclusive education?

RQ3. Is there a relationship between the presence or absence of professional development related to inclusive education and teacher attitudes toward inclusive education?

\section{Methods}

\section{Participants}

This study used an accidental sampling method, in which the researchers recruited 90 Indonesian inclusive preschool teacher participants based on the ease of finding available participants for the study (Shaughnessy, Zechmeister, \& Zechmeister, 2000; Kerlinger \& Lee, 2000) The participants were recruited from the following areas; seventy-four (82.22\%) from Greater Jakarta (Jakarta and surrounding cities of Bogor, Depok, Tangerang, and Bekasi), including forty (44.44\%) from the Special Capital Region of Jakarta (DKI Jakarta), twenty-one (23.33\%) from Depok, six (6.67\%) from Bogor, three $(3.33 \%)$ from Tangerang, and four $(4.44 \%)$ from Bekasi; four $(4.44 \%)$ from other areas in West Java, one (1.11\%) from Central Java, two $(2.22 \%)$ from East Java, six $(6.67 \%)$ from the Sumatera island cities of Palembang, Bukittinggi, and Bengkulu, and one (1.11\%) from Makassar, Celebes island. Data were obtained 
from Indonesian preschool education institutions that had implemented inclusive education and accepted SEN students.

\section{Research Design}

This study was a cross-sectional study. Data were obtained from a one-time data collection from each participant, to which correlational analyses were then applied to determine the relationships between the two research variables.

\section{Measures}

\section{Personality trait}

The traits were measured using the Neuroticism-Extraversion-Openness Personality Inventory (NEO-PI) that had been adapted into Indonesian by Rizkiah (2011). The NEOPI measures the five traits in the Five Factor Theory of Personality (McCrae and Costa) across 52 Likert type scale items with score intervals from 1 (Very Unlikely) to 6 (Very Likely), and is a multidimensional instrument; therefore, the total score is only calculated for each trait dimension. Table 1 and 2 show the NEO-PI reliability and validity indexes and the score categories.

Table I. NEO-PI Reliability and Validity

\begin{tabular}{|l|l|l|}
\hline \multicolumn{1}{|c|}{ Trait } & \multicolumn{1}{c|}{ Reliability } & \multicolumn{1}{c|}{ Validity } \\
\hline Neuroticism & 0.912 & $0.445-0.792$ \\
\hline Extraversion & 0.864 & $0.411-0.740$ \\
\hline Openness To Experience & 0.849 & $0.450-0.681$ \\
\hline Agreeableness & 0.895 & $0.415-0.805$ \\
\hline Conscientiousness & 0.875 & $0.514-0.736$ \\
\hline
\end{tabular}

Table II. NEO-PI Score Categories

\begin{tabular}{|l|l|l|l|}
\hline & \multicolumn{1}{|c|}{ Low } & \multicolumn{1}{c|}{ Average } & \multicolumn{1}{c|}{ High } \\
\hline Trait N & $11-24$ & $25-45$ & $46-66$ \\
\hline Trait E & $10-40$ & $41-51$ & $52-60$ \\
\hline Trait O & $9-33$ & $34-44$ & $45-54$ \\
\hline Trait A & $10-41$ & $42-52$ & $53-60$ \\
\hline Trait C & $12-49$ & $50-63$ & $64-72$ \\
\hline
\end{tabular}

\section{Teacher Attitudes Toward Inclusive Education}

The attitudes were measured using the Indonesian Version of the Multidimensional Attitudes Toward Inclusive Education Scale (MATIES VI), which was adapted for preschool teachers in Indonesia based on the MATIES VI adapted by Margijanto and Kurniawati (2014) for primary school teachers. The MATIES, which was constructed based on Ajzen's theory of attitude (2005), and the MATIES VI measure the cognitive, affective, and behavioral dimensions using 18 Likert type scale items with score intervals from 1 (Strongly Disagree) to 6 (Strongly Agree) This instrument is also multidimensional and therefore the total score is calculated for each dimension. 
Table III. Reliability and Validity of MATIES VI for Preschool Teachers

\begin{tabular}{|l|l|c|}
\hline \multicolumn{1}{|c|}{ Dimension } & \multicolumn{1}{c|}{ Reliability } & Validity \\
\hline Cognitive & 0.827 & $0.488-0.749$ \\
\hline Affective & 0.803 & $0.361-0.726$ \\
\hline Behavior & 0.839 & $0.209-0.827$ \\
\hline
\end{tabular}

\section{Procedure}

\section{Data Analysis}

As there was no total score that covered both the personality traits and the teacher attitudes, the data were quantitatively analyzed using the Pearson Product Moment correlation test on each trait and each attitude component. Additional analyses were conducted on the teaching experience data and whether (or not) the teachers had received inclusive education professional development (PD), for which independent measures were used; a t-test for PD and a 3-group ANOVA for teaching experience.

\section{Results}

The preschool teacher participant statistics were as follows: $97.3 \%$ female; $37.84 \%$ were between 24-30 years old, $40.54 \%$ were between $31-40$ years old, $16.22 \%$ were between $41-50$ years old, and $5.4 \%$ were in their $50 \mathrm{~s} ; 16.21 \%$ had been teaching for less than 5 years, $51.35 \%$ had been teaching for between 5-10 years, and $29.72 \%$ had been teaching for more than 10 years; 6 (6.67\%) participants had a diploma, 64 (71.11\%) had a bachelor's degree, $8(8.89 \%)$ had Master's or doctoral degrees, and 12 (13.33\%) were only high school graduates; $10(11,1 \%)$ had majored in psychology, 24 (26.67\%) in teaching arts (preschool and primary school), and 4 (4.44\%) in guidance and counseling, while more than half $(57.78 \%)$ had majored in studies unrelated to early childhood development and education such as economics, Islamic studies, and literature.

In terms of experience, $84 \%$ had had homeroom teacher, special aid teacher, or teacher assistant for SEN experience and $16 \%$ had not had direct experience even though they were working in an inclusive school. Further, 35 (38.89\%) claimed that they had only had direct SEN experience at their school, while the remainder $(62.11 \%)$ had had some experiences outside teaching, such as writing college assignments, having friends, a family member, or a neighbor who was disabled, or through social work in the community. Only $65.56 \%$ had attended inclusive education seminars, workshops, and/or training focused on information about disabilities and student special needs, information about inclusive education, strategies in handling SEN, how to develop SEN teaching methods, and other topics such as fostering independence for SEN children.

Table IV. Descriptive Statistics

\begin{tabular}{|l|l|l|l|l|}
\hline Personality Traits & \multicolumn{1}{|c|}{ Mean } & Minimum & Maximum & $\begin{array}{c}\text { Range of } \\
\text { Possible Score }\end{array}$ \\
\hline Neuroticism & 34.456 & 15 & 66 & $11-66$ \\
\hline Extraversion & 47.589 & 37 & 60 & $10-60$ \\
\hline
\end{tabular}




\begin{tabular}{|l|l|l|l|l|}
\hline $\begin{array}{l}\text { Openness to } \\
\text { Experience }\end{array}$ & 42.711 & 27 & 54 & $9-54$ \\
\hline Agreeableness & 49.689 & 39 & 60 & $10-60$ \\
\hline Conscientiousness & 58.078 & 42 & 72 & $12-72$ \\
\hline Attitude & & & & \\
\hline Cognitive & 28.056 & 18 & 36 & $6-36$ \\
\hline Affective & 27.444 & 15 & 36 & $6-36$ \\
\hline Behavior & 30.556 & 18 & 36 & $6-36$ \\
\hline
\end{tabular}

Table 4 shows that in the cognitive dimension, only trait openness to experience showed a significant correlation. However, all five traits were found to significantly correlate with the affective attitude dimension. A similar result was found for the behavioral dimension, for which four out of the five traits were found to have a significant relationship with the dimension except for neuroticism.

However, no significant differences in teacher attitudes were found for years of teaching. The affective dimension for teacher attitudes, however, was found to differ significantly for inclusive education PD, with the teachers who had had inclusive education PD seminars, workshops, and training found to have significantly more positive affective attitudes toward inclusive education $(\mathrm{t}=2.992$, sig $=0.004)$.

Table V. Correlation between the Big 5 Traits and the Three dimensions for teacher attitudes toward inclusive education

\begin{tabular}{|c|c|c|c|c|c|}
\hline $\begin{array}{c}\text { Trait } \\
\text { Attitude }\end{array}$ & Neuroticism & Extraversion & $\begin{array}{c}\text { Openness } \\
\text { to } \\
\text { Experience }\end{array}$ & $\begin{array}{c}\text { Agreeable- } \\
\text { ness }\end{array}$ & Conscientiousness \\
\hline Cognitive & -.084 & .177 & $.271^{* * *}$ & .103 & -.007 \\
\hline Affective & $-.297^{* *}$ & $.209^{*}$ & $.357^{\text {** }}$ & $.306^{* *}$ & $.274^{* *}$ \\
\hline Behavior & .062 & $.349^{* *}$ & $.417^{* *}$ & $.407^{* *}$ & $.225^{*}$ \\
\hline
\end{tabular}

\section{Discussion and Conclusion}

The cognitive dimension of teacher attitudes was found to correlate significantly with trait openness to experience, which supported Todorovic et al.'s (2011) finding. The more positive the teachers' beliefs about inclusive education, the more willing the teachers were to seek information. Therefore, teacher interventions in inclusive preschools need to provide cognitive insights to issues regarding inclusive education and SEN needs. Kolb's model for the learning cycle in Experiential Learning Theory (1984) (as cited in Laird, Naquin, \& Holton, 2003) includes the first learning stage Concrete Experience, which is the gateway to cognitive dissonance and gives insights into intervention.

The affective attitude dimension was found to significantly correlate with all 5 FFM traits. In particular, a higher level Neuroticism trait was found to correlate with more negative emotions toward SEN students, while the other four traits were found to correlate positively with the affect 
toward them, which supported the Prather-Jones (2011) and Bentea's (2015) findings on teacher positive affect especially when they had to teach SEN students.

The behavior dimension for teacher attitudes was found to significantly correlate with all FFM traits except Neuroticism, which indicated that the higher the level of these traits, the more willing teachers were to provide support and assistance to SEN students, which was in line with the findings in Bentea (2015) that teachers with positive attitudes toward their teaching profession possessed dispositions related to being "involved" and "altruistic-selfishness", which are the core characteristics of the Conscientiousness trait.

Teacher inclusive education PD was found to significantly affect their feelings toward inclusive education. While teachers may believe that SEN students are able to study in a regular classroom and show altruistic behaviors toward those students, it is the affective domain that navigates the teacher's sentiments toward SEN when they are having difficulties teaching or dealing with these students. Teachers who become upset or frustrated when having to deal with turbulence may have some knowledge regarding inclusive education and SEN, but may have difficulty regulating their own emotions toward the SEN students. It is possible that even though the inclusive education PD gave these teachers the knowledge and practical strategies to tackle SEN, the training may have not included affective content such as empathy and consideration; therefore, preschool inclusive teacher interventions need to address these issues.

However, no significant differences in teacher attitudes were found for teaching experience, which was different from Mean and Mohamed (2011)'s findings. As a majority of participants in this study $(62.11 \%)$ had had experiences of interacting with people with special needs outside of teaching, it is possible that teaching experience does not affect attitude if teachers have had such experience in non-educational interactions.

\section{Study Limitations}

The current study was unable to obtain a larger sample from all provinces in Indonesia, especially in the eastern regions such as the Maluku Islands and Papua. Given the 24-65 year old age restrictions in the Indonesian version of the NEO-PI, the researchers needed to omit participants younger than 24 years old.

\section{Suggestion for Future Research}

Some participants admitted that their school's decision to accept SEN students was merely because of the government regulation that prohibits them from turning SEN children away. Some other participants admitted that there had been some cases where the teachers had not realized that the child actually had a special need when they first enrolled, but continued to accept SEN children afterwards out of pity. Future research on this topic may also need to compare participants from preschools that have had similar experiences and preschools that actually uphold the inclusive values in their mission statements. Therefore, samples could be obtained from target preschools with such characteristics. 


\section{References}

Azjen, I. (2005). Attitudes, personality, and behavior (2 ${ }^{\text {nd }}$ ed.). New York: Open University Press.

Baron, R. A., Branscombe, N. R., \& Byrne, D. E. (2008). Social psychology. Boston, MA: Pearson/Allyn and Bacon.

Bendová, P., Čecháčková, M., \& Šádková, L. (2014). Inclusive Education of Pre-school Children with Special Educational Needs in Kindergartens. Procedia-Social and Behavioral Sciences, 112, 1014-1021.

Bentea, C. (2015). Relationships between personality characteristics and attitude towards work in school teachers. Procedia-Social and Behavioral Sciences, 180, 1562-1568.

Costa, P. T., \& Widiger, T. A. (2002). Personality disorder and the five-factor model of personality (2nd ed.). Washington: American Psychological Association.

Damon, W. (2007). Dispositions and teacher assessment: The need for a more rigorous definition. Journal of Teacher Education, 58(5), 365-369.

Darling-Hammond, L. (2006). Constructing 21st-century teacher education. Journal of Teacher Education, 57(3), 300-314.

Direktorat Pembinaan Pendidikan Khusus dan Layanan Khusus Pendidikan Dasar Kementrian Pendidikan dan Kebudayaan Republik Indonesia. (2012). Modul Pelatihan Pendidikan Inklusif. Jakarta: Direktorat Pembinaan Pendidikan Khusus dan Layanan Khusus Pendidikan Dasar.

Emam, M. M., \& Mohamed, A. H. H. (2011). Preschool and primary school teachers' attitudes towards inclusive education in Egypt: The role of experience and selfefficacy. Procedia-Social and Behavioral Sciences, 29, 976-985.

Feist, J., \& Feist, G. J. (2006). Theories of personality (6th ed.). New York: McGraw-Hill.

Gravetter, F. J., \& Wallnau, L. B. (2007). Statistics for the behavioral sciences (7th ed.). California: Thomson Wadsworth.

Jordan, A., Schwartz, E., \& McGhie-Richmond, D. (2009). Preparing teachers for inclusive classrooms. Teaching and Teacher Education, 25, 535-542.

Kerlinger, F. N. \& Lee, H. B. (2000). Foundation of behavioral research (4th ed.). Fort Worth: Harcourt College Publisher.

Kurniawati, F., Minnaert, A., Mangunsong, F., \& Ahmed, W.(2012). Empirical study on primary school teachers' attitudes towards inclusive education in Jakarta, Indonesia. Procedia-Social and Behavioral Sciences, 69, 1430-1436.

Laird, D., Holton, E. F., \& Naquin, S. S. (2003). Approaches to training and development: revised and updated. Basic Books.

Mahat, M. (2008). The development of a psychometrically-sound instrument to measure teachers' multidimensional attitudes toward inclusive education. International Journal of Special Education, 23(1), 82-92.

Margijanto, H. T., \& Kurniawati, F. (2014). Relationship between Attitude towards Inclusive Education and Teaching Strategy: A Study in Teachers with and without Direct Contact with Special Needs Children before Teaching in Inclusive Primary School (Unpublished thesis), University of Indonesia, Depok, Indonesia.

McCrae, R., \& Costa, P. T., Jr. (2003). Personality in Adulthood: A Five-Factor Theory Perspective (2nd ed.). New York: The Guilford Press.

Pallas, P. J. S. (2001). The effects of teachers' attitude on the development and implementation of inclusion: an ethnographic study of an inclusive elementary school (Doctoral thesis). Vanderbilt University, Nashville, Tennessee.

Prather-Jones, B. (2011). "Some people aren't cut out for it": the role of personality factors in the careers of teachers of students with EBD. Remedial and Special Education, 32(3), 179-191.

Rizkiah, C. (2011). The Correlation Between Trait and Psychological Well-Being on South Sumatera Society (Unpublished master thesis). University of Indonesia, Depok, Indonesia.

Robinson, D. (2017). Effective inclusive teacher education for special educational needs and disabilities: Some more thoughts on the way forward. Teaching and Teacher Education, 61, 164-178. 
Shaughnessy, J. J., Zechmeister, E. B., \& Zechmeister, J. S. (2000). Research methods in psychology (5th ed.). USA: The McGraw-Hill Companies, Inc.

Symeonidou, S., \& Phtiaka, H. (2009). Using teacher's prior knowledge, attitudes and beliefs to develop in-service teacher education courses for inclusion. Teaching and Teacher Education, 25, 543-550.

Todorovic, J., Stojiljkovic, S., Ristanic, S., \& Djigic, G. (2011). Attitudes towards inclusive education and dimensions of teacher's personality. Procedia-Social and Behavioral Sciences, 29, 426-432. 